\title{
Gondola-Shaped Luminescent Tetrarhenium Metallacycles with Crown-Ether-like Multiple Recognition Sites
}

\author{
Malaichamy Sathiyendiran, ${ }^{\dagger}$ Rong-Tang Liao, ${ }^{\dagger} \mathrm{P}$. Thanasekaran, ${ }^{\dagger}$ Tzuoo-Tsair Luo, ${ }^{\dagger}$ \\ N. S. Venkataramanan, ${ }^{\dagger}$ Gene-Hsiang Lee, ${ }^{\ddagger}$ Shie-Ming Peng, ${ }^{\ddagger}$ and Kuang-Lieh Lu ${ }^{*}, \dagger$ \\ Institute of Chemistry, Academia Sinica, Taipei 115, Taiwan, and Department of Chemistry, \\ National Taiwan University, Taipei 107, Taiwan
}

Received October 1, 2006

The self-assembly of gondola-shaped tetrarhenium metallacyclophanes was achieved in near quantitative yield from $\operatorname{Re}(\mathrm{CO})_{3}$ corners, a ditopic heterocyclic clip, and a bischelating-bridging unit using an orthogonal-bonding approach. The highly luminescent metallacycles contain crown-ether-like recognition sites, which are capable of selectively recognizing metal ions and planar aromatic molecules.

Large cavity-containing metallacycles are currently attracting a great deal of attention because of their potential applications in separation materials, as components in nanoelectronics, and as recognition elements in chemical and biological sensors. ${ }^{1-3}$ Several general synthetic approaches toward the preparation of discrete supramolecular complexes have emerged, which include directional-bonding, ${ }^{1 \mathrm{~b}-\mathrm{f}}$ symmetry interaction, ${ }^{1 \mathrm{i}-\mathrm{j}}$ and weak-link approach. ${ }^{2 \mathrm{a}}$ Recent emphasis in this field has shifted from preparing aesthetically pleasing structures to the design of functional metallacycles

* To whom correspondence should be addressed. E-mail: lu@ chem.sinica.edu.tw.

$\dagger$ Academia Sinica.

National Taiwan University.

(1) (a) Lehn, J.-M. Supramolecular Chemistry, Concepts and Perspectives; VCH: Weinheim, 1995. (b) Leininger, S.; Olenyuk, B.; Stang, P. J. Chem. Rev. 2000, 100, 853. (c) Jones, C. J. Chem. Soc. Rev. 1998 27, 289. (d) Swiegers, G. F.; Malefetse, T. J. Chem. Rev. 2000, 100, 3483. (e) Fujita, M.; Umemoto, K.; Yoshizawa, M.; Fujita, N.; Kusukawa, T.; Biradha, K. Chem. Commun. 2001, 509. (f) Sauvage, J.-P. Acc. Chem. Res. 1998, 31, 611. (g) Holliday, B. J.; Mirkin, C. A. Angew. Chem. Int. Ed. 2001, 40, 2022. (h) Cotton, F. A.; Lin, C.; Murillo, C. A. Acc. Chem. Res. 2001, 34, 759. (i) Caulder, D. L.; Raymond, K. N. Acc. Chem. Res. 1999, 32, 975. (j) Ruben, M.; Rojo, J.; Romero-Salguero, F. J.; Uppadine, L. H.; Lehn, J. M. Angew. Chem., Int. Ed. 2004, 43, 3644. (k) Severin, K. Coord. Chem. Rev. 2003, 245, 3. (1) Navarro, J. A. R.; Lippert, B. Coord. Chem. Rev. 1999, 185, 653. (m) Albrecht, M.; Janser, I.; Frohlich, R. Chem. Commun. 2005, 157.

(2) (a) Gianneschi, N. C.; Masar, M. S.; Mirkin, C. A. Acc. Chem. Res. 2005, 38, 825. (b) Kovbasyuk, L.; Kramer, R. Chem. Rev. 2004, 104, 3161. (c) Sanders, J. K. M. Chem.-Eur. J. 1998, 4, 1378. (d) Hof, F.; Rebek, J., Jr. Proc. Natl. Acad. Sci. U.S.A. 2002, 99, 4775. (e) Vriezema, D. M.; Aragones, M. C.; Elemans, J. A. A. W.; Cornelissen, J. J. L. M.; Rowan, A. E.; Nolte, R. J. M. Chem. Rev. 2005, 105, 1445. (f) Yoshizawa, M.; Tamura, M.; Fujita, M. Science 2006, 312, 251. (g) Amijs, C. H. M.; van Klink, G. P. M.; van Koten, G. Dalton Trans. 2006, 308.

10052 Inorganic Chemistry, Vol. 45, No. 25, 2006
Scheme 1. Self-Assembly of Metallacycles 1 and 2
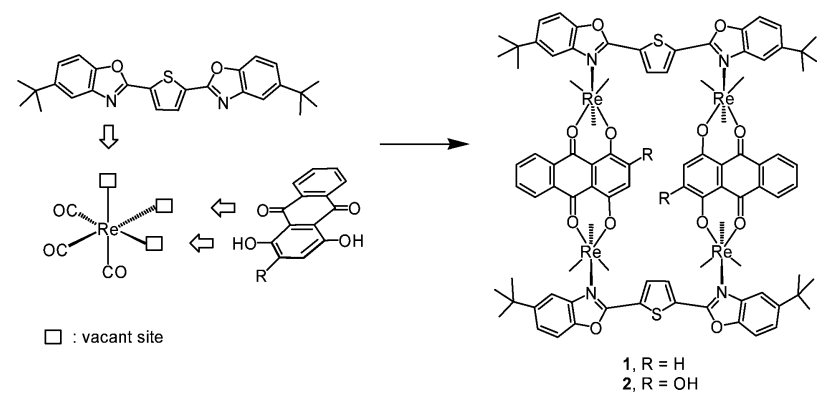

with unusual molecular sensing or catalytic properties. Examples include the development of fluorescent sensors and allosteric catalysts that mimic the properties of allosteric enzymes. ${ }^{2}$ Herein we report on a new orthogonal-bonding approach for assembling functional molecules. This approach, which is an offshoot of the directional-bonding approach, involves the simultaneous introduction of a bis(chelating) dianion to coordinate to two equatorial sites of two $f a c-(\mathrm{CO})_{3} \mathrm{Re}$ cores and a ditopic nitrogen-donor ligand to the remaining orthogonal axial site, leading to the generation of a new, hitherto unexplored class of metallacycles (Scheme 1).

As proof-of-concept, 2,5-bis(5-tert-butyl-2-benzoxazolyl)thiophene (tpbb) and 1,4-dihydroxy-9,10-anthraquinone $\left(\mathrm{H}_{2}-\right.$ dhaq) or 1,2,4-trishydroxy-9,10-anthraquinone $\left(\mathrm{H}_{2}\right.$-thaq) were chosen for use as basic building units. The presence of two nitrogen donors should permit the tpbb ligand to act as a neutral bifunctional molecular clip. We rationalized that the use of the bischelating ligands $\mathrm{H}_{2}$-dhaq and $\mathrm{H}_{2}$-thaq would result in a macrocycle host with a large internal cavity. ${ }^{4}$ Although both ligands are important in dye chemistry,

(3) (a) Dinolfo, P. H.; Hupp, J. T. Chem. Mater. 2001, 13, 3113. (b) Sun, S. S.; Lees, A. J. Coord. Chem. Rev. 2002, 230, 171. (c) Thanasekaran, P.; Liao, R. T.; Liu, Y. H.; Rajendran, T.; Rajagopal, S.; Lu, K. L. Coord. Chem. Rev. 2005, 249, 1085. (d) Slone, R. V.; Benkstein, K. D.; Belanger, S.; Hupp, J. T.; Guzei, I. A.; Rheingold, A. L. Coord. Chem. Rev. 1998, 171, 221. (e) Woessner, S. M.; Helms, J. B.; Shen, Y.; Sullivan, B. P. Inorg. Chem. 1998, 37, 5406. (f) Lee, S. J.; Lin, W. J. Am. Chem. Soc. 2002, 124, 4554. (g) Sun, S. S.; Lees, A. J. Chem. Commun. 2001, 103. Published on Web 11/09/2006 

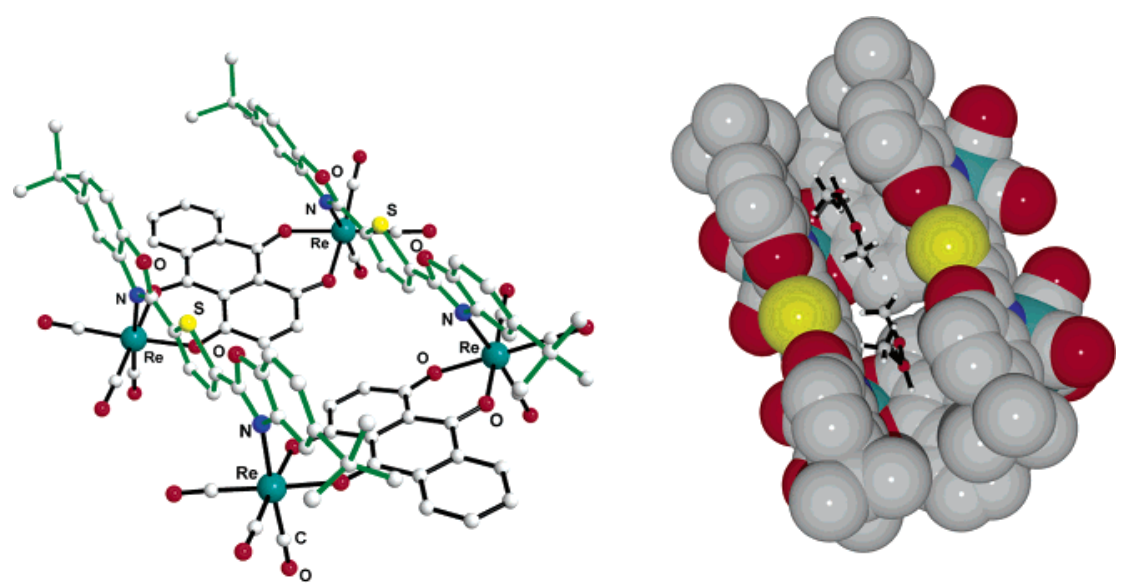

Figure 1. Crystal structure of the metallacycle 1; ball and stick representation (left); space-filling representation (right) with four methanol guests (shown in ball and stick model) occupied in the intramolecular cavity of $\mathbf{1}$.

electroluminescent devices, biology, and pharmaceutical chemistry, ${ }^{5}$ their use as building units in the construction of supramolecular assemblies has not been previously investigated. The combination of the above-mentioned new building blocks and the novel orthogonal-bonding approach permits the preparation of unique gondola-shaped structures with crown-ether-like recognition sites, highly fluorescent properties, and selective binding capabilities. This approach is so effective that the products can be prepared in near quantitative yield.

The assembly of compounds $\mathbf{1}$ and $\mathbf{2}$ was achieved by reacting equimolar amounts of $\operatorname{Re}_{2}(\mathrm{CO})_{10}$, tpbb, and $\mathrm{H}_{2}$-dhaq or $\mathrm{H}_{2}$-thaq in refluxing mesitylene. The resulting dark-green products were air and moisture stable and are slightly soluble in polar solvents. The IR spectrum of $\mathbf{1}$ in acetone exhibited strong bands at 2014 and $1900 \mathrm{~cm}^{-1}$, characteristic of fac$\operatorname{Re}(\mathrm{CO})_{3}$. The ${ }^{1} \mathrm{H}$ NMR spectrum of $\mathbf{1}$ showed well-resolved signals for each of the protons. Compared to the free ligands, the signals corresponding to the tpbb protons remained nearly unchanged, while those of the dhaq proton of $\mathrm{H}^{2}$ was shifted upfield by $0.16 \mathrm{ppm}$ after complexation with the $\operatorname{Re}(\mathrm{I})$ centers. A similar pattern was observed for $\mathbf{2}$ with an additional singlet at $10.99 \mathrm{ppm}$ corresponding to the uncoordinated hydroxyl hydrogen $\left(\mathrm{C}^{2}-\mathrm{OH}\right)$ atoms. The ESI-MS spectrum of 1 showed a molecular ion peak at $m / z$ 2418.1.

A single-crystal X-ray diffraction analysis shows that compound $\mathbf{1}$ adopts an unusual gondola-shaped structure (Figure 1). ${ }^{6}$ The structure can be regarded as a special type of grid. The two tpbb ligands serve as molecular clips, utilizing the benzoxazoline $\mathrm{N}$ atoms to bridge two doubly bridged dirhenium units. The bishydroxy anthraquinone (dhaq) acts as a doubly bridging unit using the adjacent phenolate and quinone oxygens. Interestingly, the hydrophobic internal cavity of the metallacycle is sufficiently large (size: $5.6 \AA \times 7.0 \AA \times 17.8 \AA$ ) to accommodate four $\mathrm{MeOH}$

(4) $\left[\mathrm{M}-\left(\mu_{2}-\mathrm{XR}\right)_{2}-\mathrm{M}\right](\mathrm{X}=\mathrm{O}$ or $\mathrm{S}), \sim 3.4 \AA$; $\left[\mathrm{M}-\left(\mu_{4}\right.\right.$-bisbenzimidazolate $)-\mathrm{M}], \sim 5.5 \AA,\left[\mathrm{M}-\left(\mu_{4}-2,2^{\prime}\right.\right.$-bipyrimidine $\left.)-\mathrm{M}\right], \sim 5.85 \AA$, and $\left[\mathrm{M}-\left(\mu_{4}\right.\right.$-dhaq $\left.)-\mathrm{M}\right], \sim 8.5 \AA$.

(5) (a) Yang, J.; Gordon, K. C. Chem. Phys. Lett. 2003, 375, 649. (b) Vaira, M. D.; Orioli, P.; Piccioli, F.; Bruni, B.; Messori, L. Inorg. Chem. 2003, 42, 3157. (c) Maroney, M. J.; Day, R. O.; Psyris, T.; Fleury, L. M.; Whitehead, J. P. Inorg. Chem. 1989, 28, 173. molecules. Compound $\mathbf{2}$ is isostructural with respect to $\mathbf{1}$ but contains two additional uncoordinated hydroxyl groups. It is noteworthy that compounds $\mathbf{1}$ and $\mathbf{2}$ possess multiplerecognition sites. The arrangement of heteroatoms may be considered as the structural framework of 1,10-dithio-(18crown-6) (see Supporting Information). ${ }^{7}$

Compound 1 in $\mathrm{CH}_{2} \mathrm{Cl}_{2}$ displayed intense absorption bands in the $230-395 \mathrm{~nm}$ region, which are assigned to $\pi-\pi^{*}$ transitions of the dhaq and tpbb $(357,378,397 \mathrm{~nm})$ ligands, and a weak shoulder at $420 \mathrm{~nm}$, assigned to the MLCT transition ( $\mathrm{Re} \rightarrow \mathrm{tpbb}$ ). In addition, weak absorption bands appeared at 585 and $632 \mathrm{~nm}$, attributed to an intraligand transition of the dhaq unit. Compounds $\mathbf{1}$ and $\mathbf{2}$ show a high luminescence at room temperature with a quantum yield of 0.179 for $\mathbf{1}$ and 0.397 for $\mathbf{2}$ relative to $\mathrm{Ru}(\mathrm{bpy})_{3}{ }^{2+}$. Upon excitation at $\lambda_{\max }=378 \mathrm{~nm}$, compound 1 emits a set of structured bands centered at $438 \mathrm{~nm}$ with a lifetime of 1.4 ns. These emission bands are similar to that of the tpbb ligand. The small Stokes shift and very short lifetime of $\mathbf{1}$ indicate that the emission originates from the singlet $\pi-\pi^{*}$ excited state. In the solid state, compound 1 exhibits two emission maxima at 448 and $518 \mathrm{~nm}$ when excited at 335 $\mathrm{nm}$. The emission band at $448 \mathrm{~nm}$ is due to the decay of the $\pi-\pi^{*}$ excited state of tpbb, while the band at $518 \mathrm{~nm}$ may be attributed to the decay of the $\mathrm{d}-\pi^{*} \mathrm{Re} \rightarrow$ tpbb excited state.

Preliminary studies were carried out on the host-guest chemistry of $\mathbf{1}$ using its absorption and luminescent features. The addition of metal ions such as $\mathrm{Li}^{\mathrm{I}}, \mathrm{Sr}^{\mathrm{II}}, \mathrm{Co}^{\mathrm{II}}, \mathrm{Ni}^{\mathrm{II}}, \mathrm{Cu}^{\mathrm{II}}$, $\mathrm{Zn}^{\mathrm{II}}, \mathrm{Pb}^{\mathrm{II}}$, and $\mathrm{Ag}^{\mathrm{I}}$ did not show noticeable effects on the absorption and emission bands of $\mathbf{1}$. However, upon the

(6) (a) To our knowledge, the known examples of tetranuclear fac-Re$(\mathrm{CO})_{3}$ corners-based metallacycles are either squares or rectangles (or distorted rectangles). (b) Dinolfo, P. H.; Williams, M. E.; Stern, C. L.; Hupp, J. T. J. Am. Chem. Soc. 2004, 126, 12989. (c) Dinolfo, P. H.; Hupp, J. T. J. Am. Chem. Soc. 2004, 126, 16814. (d) Dinolfo, P. H.; Lee, S. J.; Coropceanu, V.; Bredas, J. L.; Hupp, J. T. Inorg. Chem. 2005, 44, 5789. (e) Rajendran, T.; Manimaran, B.; Liao, R. T.; Thanasekaran, P.; Lee, G. H.; Peng, S. M.; Liu, Y. H.; Chang, I. J.; Rajagopal, S.; Lu, K. L. Inorg. Chem. 2003, 42, 6388. (f) Sun, S. S.; Lees, A. J. Inorg. Chem. 2001, 40, 3154. (g) Sun, S. S.; Lees, A. J. J. Am. Chem. Soc. 2000, 122, 8956.

(7) Dalley, N. K.; Smith, J. S.; Larson, S. B.; Matheson, K. L.; Christensen, J. J.; Izatt, R. M. J. Chem. Soc., Chem. Commun. 1975, 84. 


\section{COMMUNICATION}

addition of $\mathrm{Hg}^{\mathrm{II}}$ ion, the absorption maximums of $\mathbf{1}$ at 357 and $378 \mathrm{~nm}$ decreased and a new absorption peak at 425 $\mathrm{nm}$ gradually became enhanced. Similarly, the emission maximum of $\mathbf{1}$ at $438 \mathrm{~nm}$ was quenched while the emission intensity at $490 \mathrm{~nm}$ gradually increased. A plot of $1 /(\Delta I)$ vs $[\mathrm{G}]^{-1}$ at $495 \mathrm{~nm}$ showed a good linear relationship, ${ }^{8}$ indicating the formation of a 1:1 complex with a binding constant of $1.3 \times 10^{3} \mathrm{M}^{-1}$. The binding constant did not change when different counterions $\left(\mathrm{CF}_{3} \mathrm{SO}_{3}{ }^{-}, \mathrm{NO}_{3}{ }^{-}\right)$were used. The uncoordinated sulfur atoms of the tpbb ligands along with the flexibility of thiophene rings conferred by the $\sigma$-bond create a well-defined binding site for metal ion selective recognition. The adjacent hard ( $\mathrm{O}$ atoms) Lewis base sites may exhibit a synergistic effect to strengthen the recognition capability. Another option is that each half of the macrocycle is occupied by one cation. Since the host/ guest ratio is $1: 1$, the possibility that two macrocycles, with their cavities facing each other, are complexing two cations cannot be excluded. The emission enhancement of $\mathbf{1}$ may attributed to the chelation of metal ions thereby leading to more rigid complexes, which reduces the nonradiative decay process. ${ }^{9,10}$

(8) (a) Connors, A. K. Binding Constants: The Measurement of Molecular Complex Stability; Wiley: New York, 1987. (b) Benesi, H. A.; Hildebrand, J. H. J. Am. Chem. Soc. 1949, 71, 2703. (c) Demas, J. N.; Addlngton, J. W.; Peterson, S. H.; Harris, E. W. J. Phys. Chem. 1977, 81, 1039.

(9) (a) Rurack, K.; Kollmannsberger, M.; Resch-Genger, U.; Daub, J. J. Am. Chem. Soc. 2000, 122, 968. (b) Guo, X.; Qian, X.; Jia, L. J. Am. Chem. Soc. 2004, 126, 2272. (c) McClure, D. S. J. Chem. Phys. 1952, 20,682 .
Furthermore, compound $\mathbf{1}$ was capable of specifically recognizing anthracene. Quenching of the emission intensity shows that $\mathbf{1}$ has a much higher affinity for anthracene ( $K$ $\left.=3.8 \times 10^{3} \mathrm{M}^{-1}\right)$ than pyrene, naphthalene, or benzene $(K$ not detectable). The contribution of $\pi$ systems would be very important for the binding of aromatic molecules, and the preference found for anthracene may result from shape complimentarity with the anthraquinone moiety.

In conclusion, a new class of neutral, luminescent Rebased metallacycles was designed and assembled in near quantitative yield using novel orthogonal-bonding strategy. The metallacycles are remarkable in terms of their structure, blue light-emitting property, multiple functional sites, and selective binding ability toward mercury cations and anthracene molecule. The orthogonal-bonding approach was found to be extremely effective toward the design of novel functional metallacycles. Further studies are underway to establish the full scope of this methodology.

Acknowledgment. We thank Academia Sinica and the National Science Council of Taiwan for financial support.

Supporting Information Available: Synthetic procedure and spectral data for compounds $\mathbf{1}$ and $\mathbf{2}$ (PDF). The crystallographic files for compounds $\mathbf{1}$ and $\mathbf{2}$ in CIF format. This material is available free of charge via the Internet at http://pubs.acs.org.

\section{IC061886W}

(10) (a) Berton, M.; Mancin, F.; Stocchero, G.; Tecilla, P.; Tonellato, U. Langmuir, 2001, 17, 7521. (b) Ramachandram, B.; Samanta, A. Chem. Commun. 1997, 1037. (c) Xia, W. S.; Schmehl, R. H.; Li, C. J.; Mague, J. T.; Luo, C. P.; Guldi, D. M. J. Phys. Chem. B 2002, 106, 833. 